\title{
Erratum to: Transcatheter Closure of a Patent Ductus Arteriosus in a Patient With an Anomalous Inferior Vena Cava
}

Saleem Akhtar • Shazia Mohsin Samad •

Mehnaz Atiq Ahmed

Published online: 2 October 2010

(C) Springer Science+Business Media, LLC 2010

Erratum to: Pediatr Cardiol

DOI 10.1007/s00246-010-9745-2

The original version of this article unfortunately contained a mistake. The name of 1 st author was published incorrectly as A. Akhtar. The corrected affiliations are given below.

The online version of the original article can be found under doi:10.1007/s00246-010-9745-2.

S. Akhtar · S. M. Samad · M. Atiq Ahmed ( $\square)$ Section of Pediatric Cardiology, Department of Pediatrics and Child Health, Aga Khan University Hospital, P.O. Box 3500, Karachi 74800, Pakistan

e-mail: mehnaz.atiq@aku.edu 